Primljen / Received: 12.3.2014. Ispravljen / Corrected: 13.6.2014.

Prihvaćen / Accepted: 7.7.2014. Dostupno online / Available online: 1.8.2014.

\section{High performance concrete with steel slag aggregate}

Authors:

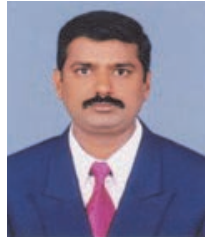

Assist.Prof. Verapathran Maruthachalam, ME CMS College of Engineering \& Technology Department of Civil Engineering Coimbatore, India mveerapathran@yahoo.com

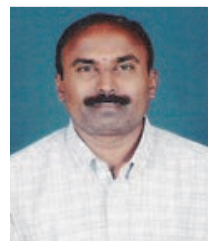

Prof. Murthi Palanisamy, PhD. CE Vivekananda College of Engineering for Women Department of Civil Engineering Tiruchengode, India drpmurthi@gmail.com

\section{Verapathran Maruthachalam, Murthi Palanisamy}

\section{High performance concrete with steel slag aggregate}

The effect of the steel slag aggregate aging on mechanical properties of the high performance concrete is analysed in the paper. The effect of different aging periods of steel slag aggregate on mechanical properties of high performance concrete is studied. It was observed that properties of this concrete are affected by the steel slag aggregate aging process. The compressive strength increases with an increase in the aging period of steel slag aggregate. The flexural strength, Young's modulus, and impact strength of concrete, increase at the rate similar to that of the compressive strength. The workability and the abrasion loss of concrete decrease with an increase of the steel slag aggregate aging period.

Key words:

high performance concrete, steel slag aggregate, abrasion, aging period, impact strength, mechanical properties

Verapathran Maruthachalam, Murthi Palanisamy

Izvorni znanstveni rad

\section{Beton visokih uporabnih svojstava sa čeličanskom zgurom kao agregatom}

U radu se analizira utjecaj starenja čeličanske zgure kao agregata na mehanička svojstva betona visokih uporabnih svojstava. Razmatra se utjecaj raznih vremena starenja na mehanička svojstva betona. Uočeno je da proces starenja zgure utječe na svojstva ovog betona. Tlačna čvrstoća betona raste usporedo s porastom vremena starenja. Savojna čvrstoća, Youngov modul i udarna čvrstoća rastu slično kao i tlačna čvrstoća. Obradivost betona i gubitak abrazijom smanjuju se s povećanjem vremena starenja.

Ključne riječi:

beton visokih uporabnih svojstava, čeličanska zgura, abrazija, vrijeme starenja, udarna čvrstoća, mehanička svojstva

Wissenschaftlicher Originalbeitrag

Verapathran Maruthachalam, Murthi Palanisamy

\section{Hochleistungsbeton mit Stahlschlacke als Zuschlagstoff}

In dieser Arbeit wird der Einfluss der Reifung von Stahlschlacke als Zuschlagstoff auf mechanische Eigenschaften von Hochleistungsbeton analysiert. Dabei ist der entsprechende Einfluss verschiedener Reifungszeiten der Stahlschlacke untersucht. Der Reifungsprozess hat sich als bedeutend für die Eigenschaften des Hochleistungsbetons herausgestellt. Die Druckfestigkeit steigt mit anwachsender Reifungszeit. Die Biegefestigkeit, der Youngsche Modul und die Stossfestigkeit wachsen ebenfalls entsprechend an. Die Verarbeitbarkeit und der Abriebverlust des Betons werden durch längere Reifungszeiten der Stahlschlacke, die als Zuschlagstoff verwendet wird, vermindert.

Schlüsselwörter:

Hochleistungsbeton, Stahlschlacke als Zuschlagstoff, Abrieb, Reifungszeit, Stossfestigkeit, mechanische Eigenschaften 


\section{Introduction}

High performance concrete is the type of concrete that meets special performance and uniformity requirements, which cannot always be fulfilled with the techniques and materials adopted for the conventional cement concrete production. The major difference between the conventional cement concrete and high performance concrete essentially lies in the use of chemical and mineral admixtures. Thus the combined use of chemical and mineral admixtures results in an economical concrete with enhanced properties [1]. The addition of mineral admixtures also reduces the quantity of cement in concrete, which directly contributes to the reduction of $\mathrm{CO}_{2}$ emissions [2]. Aggregates are important constituents in the concrete composite that help in reducing shrinkage and impart economy to concrete production. Most of the aggregates used are naturally occurring aggregates, although some artificial aggregates can also be added to concrete. These artificial and processed aggregates react with the cement paste and chemically combine to improve mechanical properties of concrete [3]. Steel slag, a byproduct of the steel making process, is produced during separation of the molten steel from impurities in the steel-making furnaces. This byproduct is broken down to smaller sizes so that it can be used as aggregate in asphalt and concrete. Netinger et al. conclude that steel slag can be used as a concrete aggregate. Such use would contribute to proper management of this type of waste, and to preservation of aggregate normally taken from nature [4]. Netinger et al. report that steel slag can be used as concrete aggregate in reinforced-concrete structures [5]. Maslehuddin et al. report that physical properties and durability characteristics of the steel slag cement concrete are better than those of the crushed lime stone aggregate concrete [6]. Akinbinu reports that the compressive strength of concrete mixes containing steel slag has a higher value when compared to laterite [7]. Shih et al. studied characteristics of the brick made of steel slag, and revealed that it reduces the required firing temperature [8]. Alizahelu et al. conclude that steel slag can be used as aggregate in concrete, but that it is more beneficial in the high strength concrete than in the normal strength concrete [9]. Wu et al. report that the high temperature property of stone mastic asphalt (SMA) mixtures with steel slag is better than the corresponding property of the SMA mixtures with basalt. Better physical properties of steel slag enhance the ability of resisting permanent deformation at high temperatures [10]. Presently, the total steel production in India amounts to approximately 72.20 million metric tons, and the steel slag waste generated annually varies around 18 million metric tons, but hardly $25 \%$ is being used in cement production [11]. During the steel making process in furnaces, the furnace is also charged with fluxing agents such as lime or dolomite in order to remove impurities from raw materials (iron and steel scrap). The impurities combine with the fluxing agents at high temperature forming a by product known as steel slag, which floats on top of the molten steel. Then the molten steel and slag are removed separately from the furnace. It should be noted that a certain amount of unburnt lime or dolomite, known as free lime, remains in steel slag (Figure 1.a). Spaces in which the free lime occurs in steel slag are known as lime pockets. This free lime is in an un-combined and unstable form in the lime pockets. This contaminated steel slag produces some serious problems by volume expansion in concrete, due to the delayed hydration of free lime. It should be noted that if steel slag is used after a sufficient period of time (e.g. one year), the risk of free lime expansion is minimized because of prior hydration of the free lime present in slag [9]. Because of its expansive nature, the steel slag must be allowed to undergo the weathering process before it can be used as aggregate in construction industry. This is done in order to bring down the quantity of free lime to acceptable limits. The steel slag is stored in stockpiles for a period of at least 4 months, where it is exposed to weather conditions [12]. Slag, and especially the steel slag, must be allowed to age for a period of time, usually 6 months, before it can be used as a road base aggregate. The primary reason for the aging process is to allow the free lime or calcium carbonate to hydrate before use, so as to prevent an excessive volume expansion [13]. The aging time should range from no less than three months to no more than 18 months, so as to reduce the volume expansion of steel slag [14]. In order to resolve this expansive behaviour, the steel slag is kept in stockpiles, exposed to weather, for a period of at least four months [15]. There are different opinions about the aging period of steel slag, and research papers on the effect of aging period of steel slag on the properties of concrete are also quite rare. Hence a detailed study has been made to evaluate the effect of different aging periods of steel slag on mechanical properties of high performance concrete. Several kinds of slag can be obtained by different processes of steel making, such as the basic oxygen slag, electric arc furnace slag, electric induction furnace slag, ladle slag, etc. This study focuses solely on the use of the electric induction furnace slag in concrete. The results obtained in this investigation could be useful in establishing better mixture proportions for the high performance concrete, using steel slag as coarse aggregate.

\section{Materials and methods}

\subsection{Materials}

An ordinary Portland cement (OPC) of grade 53 conforming to IS 12269-1987 [16], the river sand (RS) of grading zone II obtained from the Cauvery River bed at Karur, and the $20 \mathrm{~mm}$ down blended well graded hard blue granite (HBG) stone aggregates, were used in the investigation. The class $\mathrm{F}$ fly ash (FA), 2.15 in specific gravity, as obtained from the Mettur Thermal Power Station, was used as mineral admixture. The sulphonated naphthalene based superplasticizer (SP), 
Table 1. Physical and mechanical properties of cement

\begin{tabular}{|c|c|c|c|c|c|c|c|}
\hline \multirow{2}{*}{$\begin{array}{l}\text { Specific } \\
\text { gravity }\end{array}$} & \multirow{2}{*}{$\begin{array}{l}\text { Standard } \\
\text { consistency }\end{array}$} & \multirow{2}{*}{$\begin{array}{l}\text { Initial setting } \\
\text { time }\end{array}$} & \multirow{2}{*}{$\begin{array}{c}\text { Final setting } \\
\text { time }\end{array}$} & \multicolumn{3}{|c|}{ Compressive strength [MPa] } & \multirow{2}{*}{$\begin{array}{c}\text { Soundness } \\
\text { (Lechatelier) }\end{array}$} \\
\hline & & & & 3 days & 7 days & 28 days & \\
\hline 3,15 & $32 \%$ & $58 \mathrm{~min}$ & $215 \mathrm{~min}$ & 27,50 & 41,61 & 57,32 & $3 \mathrm{~mm}$ \\
\hline
\end{tabular}
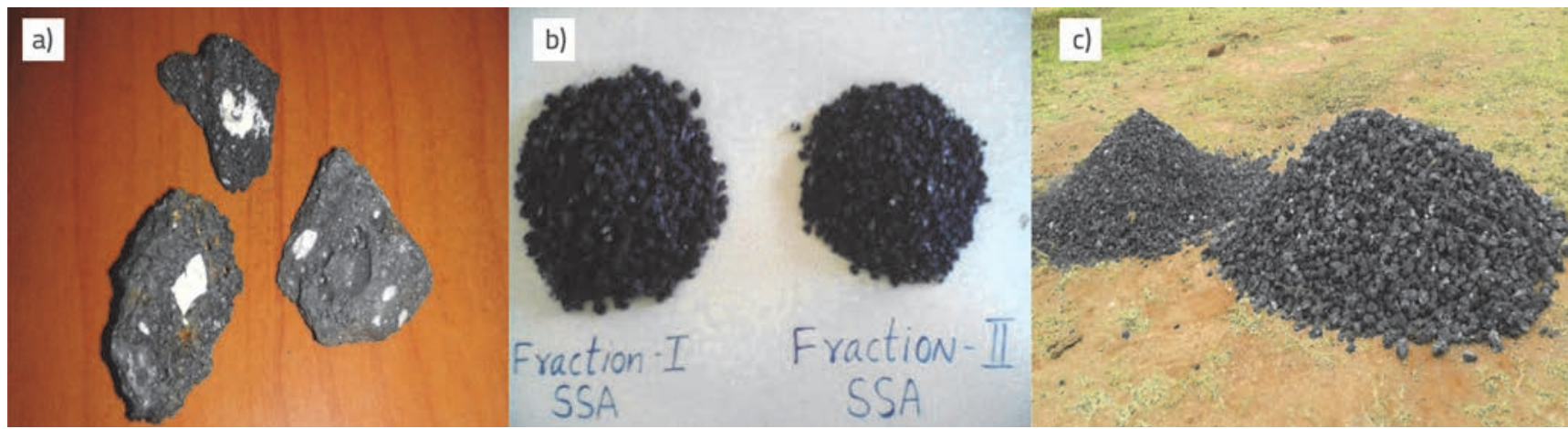

Figure 1. Steel slag aggregates: a) with free lime and rough surface; b) Fraction 1 and Fraction 2; c) at stockpile

confirming to IS 9103 -1999 [17], was used as chemical admixture. The steel slag was produced at Raja Steels Private Ltd, Coimbatore, India. Potable water was used for mixing concrete and curing of cast specimens. Physical and mechanical properties of cement were tested according to IS: 4031-1988 [18]. These properties are given in Table 1.

\subsection{Methods}

The conventional concrete (CC) was prepared as a control mix. The high performance concrete (HPC) based on conventional materials and fly ash was also prepared for a detailed study. The steel slag was obtained in form of boulders. The steel slag aggregate (SSA) was prepared by crushing the boulders and sorting them into two groups by sieving. The fraction 1 - passing through the $20 \mathrm{~mm}$ sieve and retained on the 10 $\mathrm{mm}$ sieve (F1), and fraction 2 - passing through the $10 \mathrm{~mm}$ sieve and retained on the $4.75 \mathrm{~mm}$ sieve (F2), were considered in this study (Figure 1.b). The steel slag aggregate is angular and has rough surface, as shown in Figure 1.a. This feature provides for an excellent bond with the cement paste matrix. Several aging methods are currently used to reduce the expansibility of steel slag aggregate, namely the air aging, hot water aging, and steam aging [19]. In this research, the air aging method was used (steel slag was left out in the open to enable weathering), as this method is easier and more cost effective. In this respect, the steel slag aggregate was stocked on a hard, dry and level patch of ground and arranged according to nominal sizes (Figure 1.c). It was used as coarse aggregate after every 6 months in the production of high performance concrete mixes. The aggregate sampling was carried out as per IS2340 [20]. Representative samples were taken from various levels and locations at the stock pile. Thus, samples were taken equally from the top third, mid third, and bottom third of the stocked aggregate. During the sampling process, the outer layer which may have become segregated, was removed and the sample was taken from the material beneath. Physical and mechanical properties of aggregates, presented in Table 2, were determined according to IS 23861963 [21]. They were found to be conformant with IS 3831970 [22]. The aggregate types HBG and SSA contain $60 \%$ of fraction 1 and $40 \%$ of fraction 2 particles. Sieving curves of all aggregates are presented in Figure 2.

In order to evaluate the effect of the steel slag aging period, the concrete containing steel slag aggregates (HPC1, HPC2, HPC3, HPC4, HPC5, HPC6, and HPC7) was investigated at different aging periods $(6,12,18,24,30,36,42$ months). The mix design was carried out as per ACl 211.4R-93 [23] to obtain the M60 grade concrete. After extensive trials, it was established that the water cement ratio $(\mathrm{w} / \mathrm{c}$ ) and the cement content amount to 0.32 and $584 \mathrm{~kg} / \mathrm{m}^{3}$, respectively. The absolute volume method was used in the calculation of concrete mixtures to

Table 2. Physical and mechanical properties of aggregates

\begin{tabular}{|c|c|c|c|c|c|c|c|}
\hline Aggregate type & Specific gravity & $\begin{array}{c}\text { Fineness } \\
\text { modulus }\end{array}$ & $\begin{array}{c}\text { Water } \\
\text { absorption } \\
{[\%]}\end{array}$ & $\begin{array}{c}\text { Unit weight } \\
{\left[\mathrm{kg} / \mathrm{m}^{3}\right]}\end{array}$ & $\begin{array}{c}\text { Crushing value } \\
{[\%]}\end{array}$ & $\begin{array}{c}\text { Impact } \\
\text { value } \\
{[\%]}\end{array}$ & $\begin{array}{c}\text { Abrasion } \\
\text { value } \\
{[\%]}\end{array}$ \\
\hline Hard blue granite & 2,71 & 7,06 & 0,40 & 1719 & 26 & 25 & 23 \\
\hline Steel slag & 2,89 & 6,64 & 1,90 & 1611 & 27 & 23 & 29 \\
\hline River sand & 2,64 & 2,67 & 1,00 & 1669 & ---- & ---- & --- \\
\hline
\end{tabular}


Table 3. Mix proportions for various mixes

\begin{tabular}{|c|c|c|c|c|c|c|c|c|c|c|c|c|}
\hline \multirow{3}{*}{ No } & \multirow{3}{*}{$\begin{array}{c}\text { Mix } \\
\text { designation }\end{array}$} & \multirow{3}{*}{$\begin{array}{l}\text { Water cement } \\
\text { ratio }\end{array}$} & \multicolumn{9}{|c|}{ Materials $\left[\mathrm{kg} / \mathrm{m}^{3}\right]$} & \multirow{3}{*}{$\begin{array}{c}\text { Agging } \\
\text { [months] }\end{array}$} \\
\hline & & & \multirow{2}{*}{ Cement } & \multirow{2}{*}{$\begin{array}{l}\text { Fly } \\
\text { ash }\end{array}$} & \multirow{2}{*}{$\begin{array}{l}\text { River } \\
\text { sand }\end{array}$} & \multicolumn{2}{|c|}{ Hard blue granite } & \multicolumn{2}{|c|}{ Steel slag } & \multirow{2}{*}{ Water } & \multirow{2}{*}{ Superplastifikator } & \\
\hline & & & & & & F1 & F2 & F1 & F2 & & & \\
\hline 1 & CC & 0,32 & 584 & - & 596 & 687 & 458 & - & - & 187 & - & - \\
\hline 2 & HPC & 0,32 & 438 & 146 & 596 & 687 & 458 & - & - & 187 & 11,7 & - \\
\hline 3 & HPC1 & 0,32 & 438 & 146 & 596 & - & - & 716 & 478 & 187 & 11,7 & 6 \\
\hline 4 & HPC2 & 0,32 & 438 & 146 & 596 & - & - & 716 & 478 & 187 & 11,7 & 12 \\
\hline 5 & HPC3 & 0,32 & 438 & 146 & 596 & - & - & 716 & 478 & 187 & 11,7 & 18 \\
\hline 6 & HPC4 & 0,32 & 438 & 146 & 596 & - & - & 716 & 478 & 187 & 11,7 & 24 \\
\hline 7 & HPC5 & 0,32 & 438 & 146 & 596 & - & - & 716 & 478 & 187 & 11,7 & 30 \\
\hline 8 & HPC6 & 0,32 & 438 & 146 & 596 & - & - & 716 & 478 & 187 & 11,7 & 36 \\
\hline 9 & $\mathrm{HPC7}$ & 0,32 & 438 & 146 & 596 & - & - & 716 & 478 & 187 & 11,7 & 42 \\
\hline
\end{tabular}

obtain denser concrete. Unlike conventional concrete, the main feature of high performance concrete is the inclusion of chemical and mineral admixtures. In this paper, the sulphonated naphthalene based superplasticizer was used as chemical admixture, and the Class F fly ash was used as mineral admixture at $2 \%$ and $25 \%$ of weight of cement, as per guidelines given in ACl 211.4R-93 [23] and IS 456-2000 [24]. Mix proportions for various mixtures are given in Table 3.

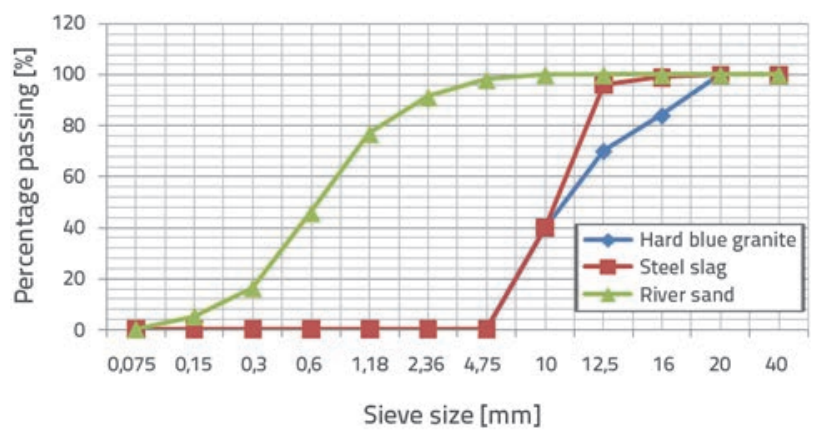

Figure 2. Sieving curves of aggregates

The SSA has a higher specific gravity when compared to other aggregates used in this work. Hence, the mixing procedure adopted by Gencel et al. [25] was applied, because the authors used this procedure for heavy weight aggregates. Ingredients weighed for the batch were mixed in a tilting drum type concrete mixer. The materials were added to the concrete mixture in the following order: coarse aggregate, fine aggregate, and cement. Initially, dry materials were mixed for one minute, and then $80 \%$ of water was added. After 1.5 minutes of mixing, the rest of the mixing water was added. All batches were mixed for the total time of 5 minutes. In order to prevent segregation of fresh concrete, the mixing duration was kept as low as possible. The workability (slump) of concrete produced was determined according to IS 1199-1959 [26].The specimens were cast in steel moulds and compacted using a tamping rod. About $24 \mathrm{~h}$ after casting, specimens were de-moulded and immediately placed in a water tank for curing. The compressive strength, flexural strength, and Young's modulus values of concrete were determined according to IS 516-1959 [27]. The cubic specimens measuring $150 \times 150 \times 150 \mathrm{~mm}$ were used for the compressive strength testing. The flexural strength testing was conducted on $100 \times 100 \times 500 \mathrm{~mm}$ prisms. The modulus of elasticity was determined by compression of cylindrical specimens measuring $150 \mathrm{~mm}$ in diameter and $300 \mathrm{~mm}$ in length. The impact strength of concrete was determined as per ACl 544.2R-89 [28]. Concrete discs $150 \mathrm{~mm}$ in diameter and $65 \mathrm{~mm}$ in thickness were used for this purpose. The specimens were placed exactly at the bottom centre of the circular base plate. The hammer was raised to its top position and dropped freely. The procedure was repeated until failure. The number of blows required to reach the specimen failure was then noted.

The impact strength of the specimen is calculated as given in Equation (1).

Impact strength $=\mathrm{m} \cdot \mathrm{g} \cdot \mathrm{h} \times$ number of blows

where:

m - mass of hammer

g - acceleration due to gravity

h - height of fall

The abrasion resistance of concrete was determined according to Turkish standard specifications TS699. Although this standard is highly recommended for the abrasion of natural stones, it is also applied for concrete specimens as an alternative to ASTM C779 [29]. Many researchers have used this method and obtained reliable results [25, $30,31] .70 \times 70 \times 50 \mathrm{~mm}$ samples were used to determine the abrasion resistance of concrete. In compliance with TS699, the abrasion system consisted of a steel disc 750 $\mathrm{mm}$ in diameter with the rotating speed of $30 \pm 1$ cycles/ 
min, a counter, and a lever. In the test procedure, $20 \pm 0.5$ $\mathrm{g}$ of abrasion dust was spread on the disc, the specimen was placed in position, the load of $5 \mathrm{~kg}$ was applied to the specimen, and the disc was rotated for four periods (one period equalling 22 cycles). After that, the surfaces of the disc and the sample were cleaned. The above-mentioned procedure was repeated for each edge of concrete samples by rotating the sample for $90^{\circ}$ in each period. Corundum was used as abrasive dust in this test. The wear of the specimen is determined from the difference in readings obtained by the measuring gauge before and after abrasion of the specimen. For all the tests and for every test age, as shown in Table 4, three specimens were cast and tested for each mix, and an average value was taken for the study.

Table 4. Testing age of concrete specimens

\begin{tabular}{|c|c|}
\hline Test & Test age \\
\hline Compressive strength & 7 days, 28 days, 56 days and 91 days \\
\hline Flexural strength & 7 days and 28 days \\
\hline Modulus of elasticity & 7 days and28 days \\
\hline Impact test & 7 days and 28 days \\
\hline Abrasion test & 7 days and 28 days \\
\hline
\end{tabular}

\section{Results and discussion}

\subsection{Workability}

Slump test results are shown in Figure 3. As can be seen in Figure 3, the workability of all high performance concrete (HPC) mixes is higher than that of conventional concrete (CC), because of the addition of fly ash and superplasticizer. The spherical shape of fly ash particles and their smaller grain size have a beneficial effect on workability. The workability of HPC mixes containing steel slag aggregate (SSA) decreased with an increase in the aging period of SSA. As the aging period increased, the hardness and surface roughness of SSA also increased due to weathering, which resulted in harsh mix with a reduced workability. The proportion of the super plasticizer may be increased so as to increase the workability. However, it was kept constant in this research to enable a more accurate comparison.

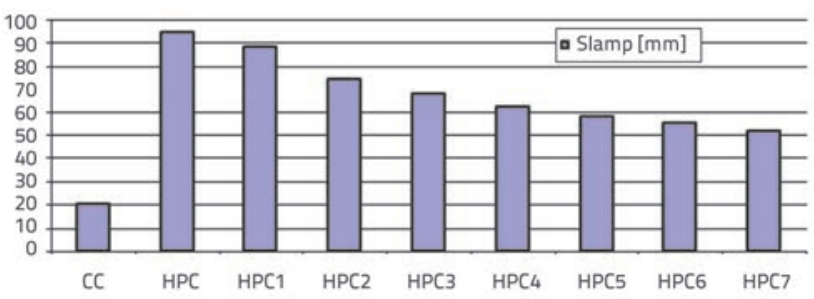

Figure 3. Slump test results

\subsection{Compressive strength}

Compressive strength results are presented in Table 5. It was expected that the increase in the aging period of steel slag aggregate will bring about an increase in compressive strength.

Table 5. Compressive strength results

\begin{tabular}{|c|c|c|c|c|c|}
\hline \multirow{2}{*}{ No } & \multirow{2}{*}{$\begin{array}{c}\text { Mix } \\
\text { designation }\end{array}$} & \multicolumn{4}{|c|}{ Compressive strength [MPa] } \\
\cline { 3 - 6 } & 7 days & $\mathbf{2 8}$ days & $\mathbf{5 6}$ days & 91 days \\
\hline 1 & CC & 40,12 & 61,24 & 64,52 & 66,78 \\
\hline 2 & HPC & 26,25 & 44,83 & 65,94 & 74,98 \\
\hline 3 & HPC1 & 20,16 & 30,79 & 48,94 & 60,58 \\
\hline 4 & HPC2 & 21,43 & 32,00 & 50,15 & 61,76 \\
\hline 5 & HPC3 & 22,44 & 36,08 & 52,19 & 63,88 \\
\hline 6 & HPC4 & 24,56 & 44,28 & 54,28 & 65,95 \\
\hline 7 & HPC5 & 28,10 & 60,11 & 68,15 & 73,98 \\
\hline 8 & HPC6 & 29,07 & 62,86 & 69,84 & 77,56 \\
\hline 9 & HPC7 & 30,06 & 63,96 & 70,68 & 78,50 \\
\hline
\end{tabular}

Compressive strength of produced concretes ranged between 20.16 MPa and 40.12 MPa on day 7, between 30.79 MPa and $63.96 \mathrm{MPa}$ on day 28, between 48.94 MPa and 70.68 MPa on day 56, and between $60.58 \mathrm{MPa}$ and $78.50 \mathrm{MPa}$ on day 91. The highest compressive strength was achieved for the mix HPC7 at all ages of concrete, except at 7days. The compressive strength of mix HPC7 is by $4 \%, 10 \%$, and $18 \%$ higher than that of the CC at the ages of 28 days, 56 days, and 91 days, respectively. Alizadeh et al. [9] report that slag aggregate concretes achieve higher values of compressive strength, tensile strength, flexural strength and modulus of elasticity, compared to natural aggregate concrete. Present results are found to be in good agreement with reported results [9], except at 7 days. The relationship between the aging period of SSA and compressive strength is presented in Figure 4.

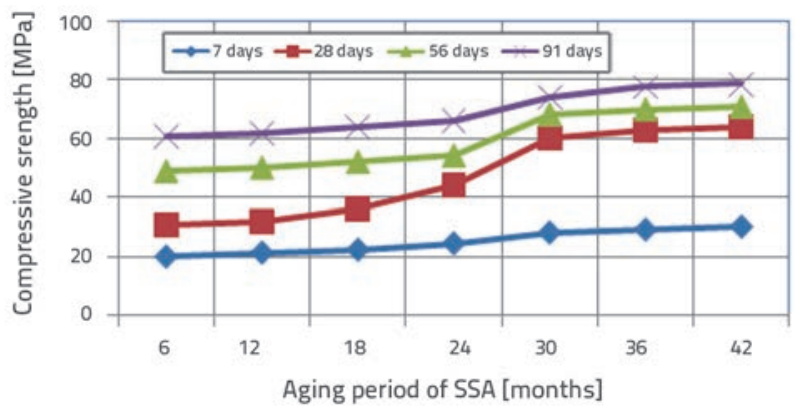

Figure 4. Relationship between aging period of steel slag aggregate (SSA) and compressive strength

As shown in Figure 4, an increase in the aging period of SSA brings about an increase in compressive strength. But at the same time, an increase in the compressive strength gain after 
30 to 36 months was found to be quite minute at all testing ages of concrete (e.g. at 28 days, the compressive strength of $\mathrm{HPC5}=60.11 \mathrm{MPa}, \mathrm{HPC6}=62.86 \mathrm{MPa}$, and HPC7 = 63.96 MPa). Hence it can be concluded that a minimum of 30 to 36 months of steel slag aging is required to achieve the compressive strength equal to that of CC (i.e., at 28 days the compressive strength of CC amounts to 61.24 MPa).

\subsection{Flexural strength}

The flexural strength of concrete is given in Figure 5. It was observed that the flexural strength of HPC mixes containing steel slag aggregates is higher than that of CC after 28 days of curing. The highest flexural strength at 7 and 28 days was achieved for HPC7 containing SSA. The flexural strength achieved in this mix is by $88 \%$ and $46 \%$ higher than that of CC at 7 and 28 days, respectively. The reason behind the improved flexural strength is the great bond between angular and rough surfaced steel slag aggregates and the paste.

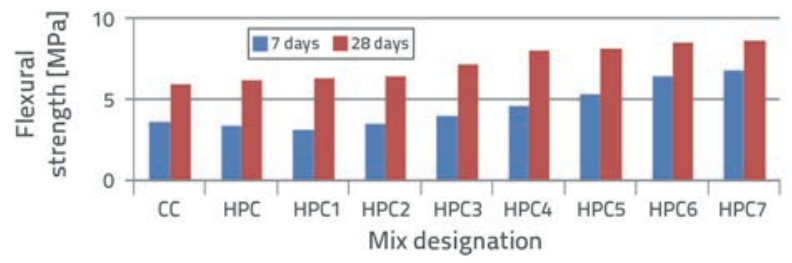

Figure 5. Flexural strength of concrete

\subsection{Young's modulus}

Young's moduli of concrete are given in Figure 6. The Young's modulus of concrete mixes containing SSA is smaller or comparable to that of CC after 7 days of curing. But after 28 days of curing, the Young's modulus of concretes HPC, HPC4, HPC5, HPC6, and HPC7 is by $3 \%, 4 \%, 8 \%, 12 \%$, and $15 \%$ higher than that of CC. However, the Young's modulus of concretes $\mathrm{HPC} 1, \mathrm{HPC} 2$ and HPC3 is smaller than that of CC.

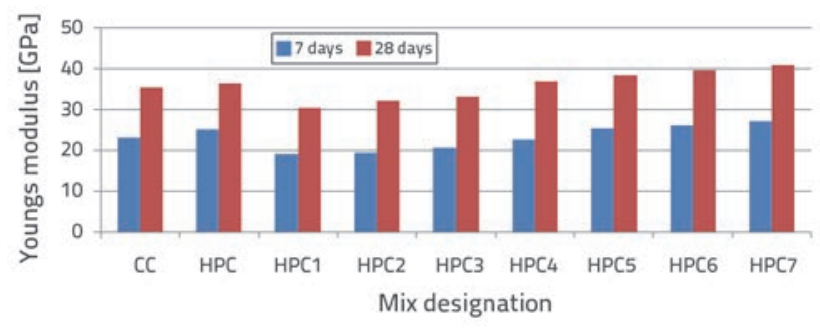

Figure 6. Young's modulus of concret

\subsection{Impact strength}

Impact strength results for concretes subjected to testing are given in Figure 7.a, while the failure pattern of impact test specimens is shown in Figure 7.b. The impact strength of concrete ranged between $342.58 \mathrm{Nm}$ and $756.78 \mathrm{Nm}$ on day 7, and between $712.56 \mathrm{Nm}$ and $1209.40 \mathrm{Nm}$ on day 28. Based on these results, the impact strength of HPC6 and HPC7 is higher than that of CC after 7 days of curing. The impact strength obtained for these concrete mixes was by $17 \%$ and $28 \%$ higher than that of CC. The impact strength of HPC, HPC4, HPC5, HPC6, and HPC7 is higher than that of CC after 28 days of curing. The impact strength obtained for these concrete mixes was by $1 \%, 0.5 \%, 18 \%, 21 \%$, and $24 \%$ higher than that of CC. However, the impact strength of concretes HPC1, HPC2, and HPC3 was smaller than that that of CC.
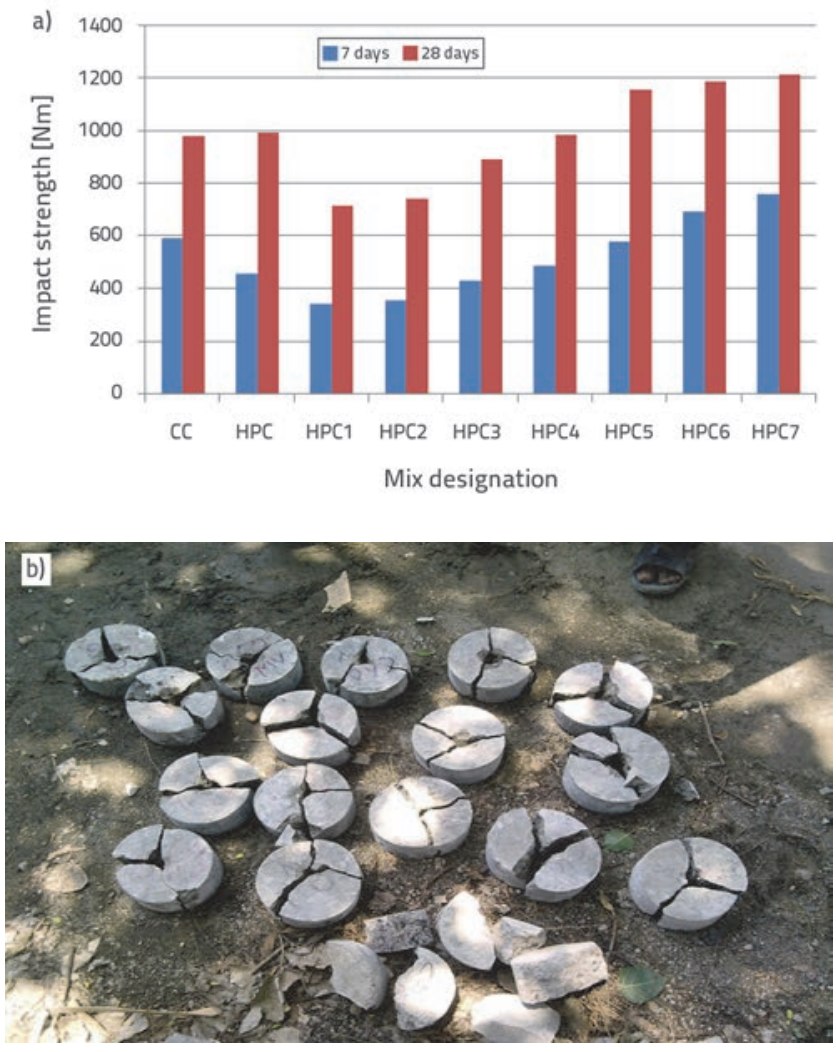

Figure 7. Impact strength of concrete: a) results of testing; b) failure pattern at impact strength testing

\subsection{Abrasion}

Values of abrasion loss of concrete are given in Figure 8. The abrasion loss of concrete decreases with an increase in the aging period of SSA. This shows that just like in case of the compressive strength, flexural strength, Young's modulus, and impact strength, the abrasion resistance of concrete increases significantly with the aging period of SSA. The relationship between the compressive strength and abrasion loss of concrete (at 28 days of age) is presented in Figure 9. As can clearly be seen in this figure, the abrasion loss of concrete mixes decreases with an increase in compressive strength. The HPC7 mix has the highest compressive strength and the lowest abrasion loss. 


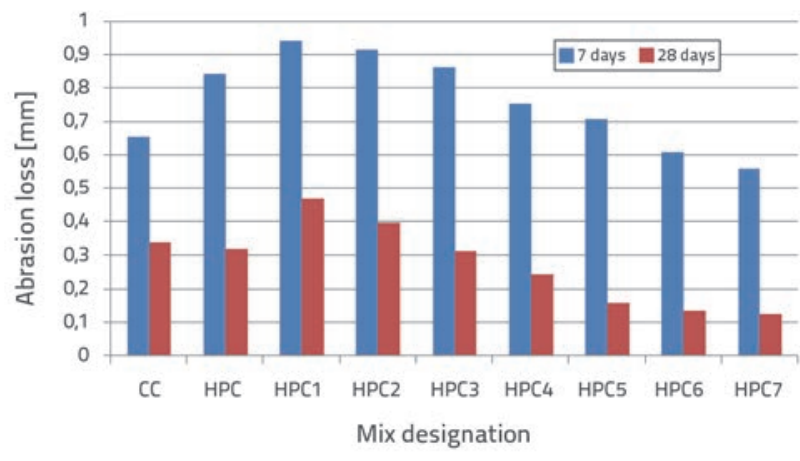

Figure 8. Abrasion loss of concrete

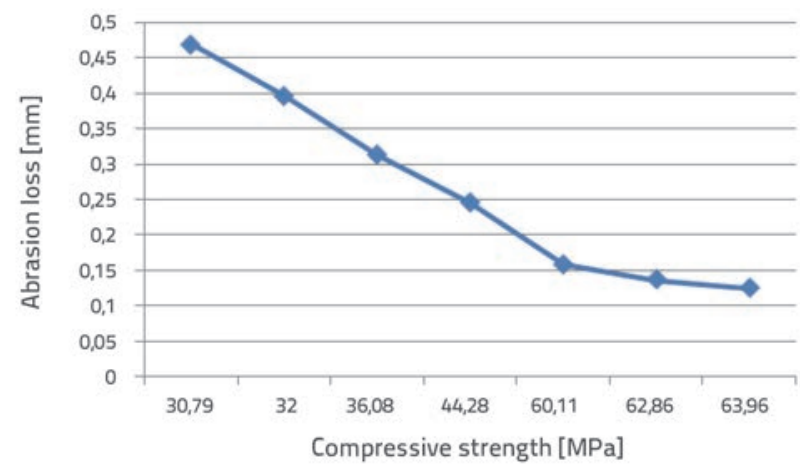

Figure 9. Relationship between compressive strength and abrasion loss of concrete

\section{Conclusion}

The several very important conclusions can be drawn from the results of this study.

Physical and mechanical properties of the steel slag aggregate are similar to those of natural aggregate. Hence the former can be utilized as an alternative to natural aggregate in concrete production. The aging process of steel slag affects the properties of concrete made with steel slag as coarse aggregate.

If the steel slag aggregates are used in concrete prior to aging, the free lime particles in the lime pockets of the steel slag aggregates may react with water and expand individually, producing uneven stress, and resulting in poor quality of concrete. When the steel slag aggregates are subjected to aging at stockpiles, the risk of free lime expansion is minimized because of the prior hydration of free lime content, due to continuous weathering in open air, contact with rain water, humidity, etc. After a long aging period, the free lime is completely removed by the weathering process. Hence the lime pockets of the steel slag become empty, which leads to an increased surface area of steel slag aggregates, and to an enhanced interlocking between aggregates and the cement paste. Therefore, the quality of concrete will be better if the steel slag aggregates are used after aging. The workability of concrete decreases with an increase in the aging period of steel slag aggregates. An increase in the aging period of steel slag aggregate brings about an increase in compressive strength. The highest compressive strength achieved in concrete with steel slag as coarse aggregate is by $4 \%, 10 \%$, and $18 \%$ higher (in HPC7) when compared to conventional concrete at 28 days, 56 days and 91 days, respectively. A minimum of 30 to 36 months of steel slag aging is required to achieve the compressive strength equal to that of conventional concrete. Thus, it might be sufficient to allow for the steel slag aging up to that period because it was observed that, beyond that period, an increase in strength results was quite minute. The flexural strength, Young's modulus, and impact strength of concrete increased with an increase in compressive strength. The abrasion loss of concrete decreased with an increase in compressive strength. This shows that the 'abrasion resistance of concrete" also increases significantly with the aging period of SSA. In general, the comparison of all strength results for control mix and HPC mixes shows that the HPC mix results are lower at an early age. Thereafter, at later ages, due to delayed action of fly ash and steel slag, all test results are comparable or higher than those relating to the control mix. It can be concluded that, after sufficient aging, the steel slag can be used as concrete aggregate along with chemical and mineral admixtures, to produce a higher quality concrete.

\section{LITERATURA}

[1] Bharatkumar, B.H., Raghuprasad, B.K.: Effect of fly ash and slag on the fracture charecteristics of high performance concrete, Materials and Structures, 38 (2005) Jan-Feb, pp. 63-72.

[2] Skazlic, M., Vujica., M.: Environmentally-friendly self-compacting concrete, GRADEVINAR 64 (2012) 9, pp. 905-913.

[3] Singha Roy, D.K.: Suitability of blast furnace slag as coarse aggregate in concrete, IE(I) Journal, 88 (2007), May, pp. 57-61.

[4] Netinger, I., Jelcic Rukavina, M., Bjegovic, D.: Possibility of using domestic slag as concrete aggregate, GRADEVINAR 62 (2010) 1, pp. 35-43.
[5] Netinger, I., Bjegovic, D., Varevac, D., Morić D.: Use of slag from steel industry as concrete aggregate, GRADEVINAR 63 (2011) 2, pp. 169-175.

[6] Maslehuddin, S., Alfarabi, M.: Comparisson of properties of steel slag and crushed lime stone aggregate concrete, Construction and building materials 17 (2003), pp. 105-112.

[7] Akinbinu, V.A.: Comparisions of compressive strength of concrete block made with steel slag waste and iron ore tailing aggregate,Proceedings of the $25^{\text {th }}$ International Conference on of solid waste technology and management, March 14-17, 2010, Philadelphia, USA. 
[8] Shih, P.H., Wu, Z.Z., Chiang, H.L.: Charateristics of bricks made from waste steel slag, Waste Management, 24 (2004) 10, pp. $1043-1047$.

[9] Alizadeh, R., Chini, M., Ghods, P.: Utilization of EAFS as aggregate in concrete - Environmental issue, Sixth CANMET/AC international conference on recent trends in advanced concrete technology, Bucharest, Romania, June 2003, pp. 451 - 464.

[10] Shaopeng, W., Youngjie, X., Qunshan Y.: Utilization of steel slag as aggregate for stone mastic asphalt (SMA) mixtures, Building and Environment, 42 (2007), pp. 2580 - 2585.

[11] Nadeem, M., Pofale, A.D.: Experimental investigation of using slag as alternative to normal aggregates in concrete, International journal of Civil and Structural Engineering, 3 (2012), pp. $117-127$.

[12] Patel, J.P.: Broader use of steel slag aggregates in concrete,Thesis of Masters of sciencedegree in civil engineering, Department of civil and Environmental engineering, Cleveland state university، December, 2008

[13] Kalyoncu, R.S.: Slag-Iron and Steel, U.S. Geological Survey Minerals Yearbook-2001, pages 70.1-70.7, <http://minerals. usgs.gov/minerals/pubs/commodity/iron_\&_steel_ slag/790401.pdf>

[14] User Guidelines for Waste and Byproduct Materials in Pavement Costruction, Publication Number: FHWA-RD97-148.,United States Department of Transportation - Federal Highway Administration.<http://www.fhwa.dot.gov/publications/ research/infrastructure/structures/97148/for.cfm>

[15] Ameri, M., Shahabishahmiri, H.: Evaluation of the use of steel slag in concrete, 25th ARRB Conference -Shaping the future, Linking policy, research and outcomes, Perth, Australia 2012.

[16] IS12269:1987, Specification for 53 Grade Ordinary Portland Cement,Bureau of Indian Standards, New Delhi, India.

[17] IS 9103:1999, Specification for admixtures for concrete, Bureau of Indian Standards, New Delhi, India.

[18] IS4031:1988, Method of physical test for hydraulic cement, Bureau of Indian Standards, New Delhi, India.
[19] Moon, H.J., Yoo, J.H., Kim, S.S.:A Fundamental Study on the Steel Slag Aggregate for Concrete,Geosystem Eng., 5 (2002)2, pp. 3845.

[20] IS 2340:1986, Methods for sampling of aggregates for concrete, Bureau of Indian Standards, New Delhi, India

[21] IS 2386:1963, Methods of test for aggregates for concrete,Bureau of Indian Standards, New Delhi, India

[22] IS 383-1970, Specification for coarse and fine aggregates from natural sources for concrete. Bureau of Indian Standards, New Delhi.

[23] ACl211.4R-93, Guide for selecting proportions for High Strength concrete with Portland Cement and fly ash, Reported by ACl Committee 211, American Concrete Institute, Detroit, USA

[24] IS: 456 - 2000, Code of practice for Plain and Reinforced Concrete, Bureau of Indian Standards, New Delhi, India

[25] Gencel, O., Ozel, C., Filiz, M.: Investigation on abrasive wear of concrete containing hematite, Indian journal of Engineering and material sciences,18 (2011), Feb, pp. $40-48$.

[26] IS 1199:1959, Methods of sampling and analysis of concrete, Bureau of Indian Standards, New Delhi, India

[27] IS: 516-1959,Methods of tests for strength of concrete, Bureau of Indian Standards, New Delhi, India

[28] ACl544.2R-89, Measurement of Properties of Fiber Reinforced Concrete, Reported by ACI Committee 544, American Concrete Institute, Detroit, USA

[29] ASTM C799, Test methods for abrasion resistance of horizontal concrete surfaces, ASTM Standards,2002

[30] Oymael, S., Yeginobali, M.A.: The effect of bituminous schist on abrasion resistance of concrete, Fourth National conference on concrete, mineral and chemical admixtures in concrete technology, Istanbul, 1996, pp. $359-367$.

[31] Turk, K., Karatap, M.: Abrasion resistance and mechanical properties of self compacting concrete with different dosages of fly ash/silica fume, Indian journal of Engineering and material sciences, 18 ( 2011) Feb, pp. $49-60$. 